\title{
MODEL KELEMBAGAAN KEMITRAAN USAHA KEBUN KELAPA SAWIT DESA (Studi Kasus Kebun Kas Masyarakat Desa Di Kabupaten Mukomuko)
}

Izharudin .

(Di bawah bimbingan Elfindri, Mahdi dan Melinda Noer)

\section{RINGKASAN}

Kelembagaan pertanian adalah norma atau kebiasaan yang terstruktur dan terpola serta dipraktekkan terus menerus untuk memenuhi kebutuhan anggota masyarakat yang terkait erat dengan kehidupan dari bidang pertanian pedesaan. Dalam kehidupan komunitas petani, posisi dan fungsi kelembagaan petani merupakan pranata sosial yang memfasilitasi interaksi sosial (social interplay)dalam suatu komunitas. Kelembagaan petani juga memiliki titik strategis dalam menggerakkan sistem agribisnis pedesaan. Saat ini potret petani dan kelembagaan petani di Indonesia diakui masih belum sebagaimana diharapkan (Suradisastra,2008). Berbagai kelembagaan kemitraaan telah dikembangkan pada komoditas pertanian, namun sebagaian besar belum menunjukkan kinerja optimal, kecuali pada sebagian komoditas perkebunan, khususnya kelapa sawit . Keberhasilan komoditas ini memiliki jangkauan pasar yang lebih luas dan adanya pengembangan pabrik pengolahan (Erwidodo, 1995).

Kelembagaan kemitraan usaha telah diterapkan pemerintah dalam pembangunan perkebunan, dengan tujuan semua pihak yang terlibat di dalamnya sama-sama memiliki manfaat. Dalam pelaksanaannya tidaklah semudah dalam perencanaan, bahkan kemitraan yang melibatkan pemerintah justru menambah kesulitan dan menimbulkan distorsi (Raharjo, 1990). Hal yang sama juga dikemukakan oleh Syahyuti (2004), dimana peran pemerintah yang terlalu dominan dalam kemitraan justru akan menghasilkan iklim yang kurang baik. Sebaliknya kemitraaan yang terbentuk dengan sendirinya, khususnya di daerah sentra produksi pertanian dianggap lebih berhasil. Hal ini disebabkan oleh adanya ketergantungan dan kebutuhan bersamaan. 
Hasil temuan Aksi kolektif pengelolaan kebun kelapa sawit desa yang teridentifikasi pada lokasi penelitian berupa: aturan informal, diimplementasikan dalam model pengelolaan kebun kelapa sawit desa. Pengelolaan kebun berbasis masyarakat tanpa melibatkan pemerintah. Adanya kesepakatan besama untuk memanfaatkan hutan desa, perencanaan, monitoring, peliharaan ditentukan dari hasil rapat bersama. Institusi adat memainkan peranan penting dalam pengelolaan kelembagaan kemitraan perkebunan kelapa sawit desa.

Hasil penjualan sebagian dialokasikan untuk pembayaran hutang, biaya operasional, penerimaan desa. Setiap masyarakat desa yang menjadi anggota kepanitaan desa/ koperasi kebun kas desa berhak atas fasilitas yang dibiayai dengan dana kebun kas masyarakat desa selain itu juga berhak menerima hasil secara langsung dari apa yang di hasilkan kebun kas masyarakat desa. Cara pemanfaatan hasil kebun Kas Masyarakat Desa, tergantung hasil dari interaksi di lapangan arena aksi, karena ini merupakan hasil pola interaksi atau pola kebiasaan pengelolaan yang dilakukan oleh para aktor. Pola interaksi yang didasarkan saling percaya dan saling menguntungkan antara PT. Agromuko dan Kepanitian Desa atau koperasi, aparat desa dan masyarakat yang terlibat memungkinkan keberhasilan. Lancarnya alur informasi yang diperlukan para pihak memudahkan interaksi, membuat rencana atau keputusan, dapat dilihat dari kelembagaan kemitraan. Aksi arena ini mendatangkan outcome berupa : konflik, keadilan, ekonomi dan keuangan.

Di kabupaten Mukomuko terdapat sebanyak 10 buah perusahaan - perusahaan perkebunan kelapa sawit berskala besar dengan luas area seluas 59,894.67 Ha. Tak jarang perusahaan-perusahaan ini mengalami hubungan-hubungan berkonflik dengan berbagai kelompok masyarakat desa. Dapat di artikan bahwa tidak ada perusahaanperusahaan perkebunan yang beroperasi di kaupaten Mukomuko yang tidak mengalami konflik dengan masyarakat sekitar perkebunan.

Hambatan terbesar dalam melakukan proses pengelolaan perkebunan yang berkeadilan dan berkelanjutan adalah transparansi serta akuntabilitas. Dalam pengelolaan kebun kas masyarakat desa telah mengacu pada upaya pemerataan 
pemanfaatan hasil. Pembangunan infrastrukur desa, sarana sosial yang dibiayai dari hasil kas masyarakat desa, bahkan di desa Pondok Batu masyarakat menikmati secara langsung uang tunai dari hasil usaha kebun kas masyarakat desa. Pembagian uang tunai secara merata berdasar pada jumlah dana yang bisa dibagi dan jumlah kepala keluarga yang berhak menerima. Pada tahun 2012 masyarakat menerima uang sebesar Rp. 1.400.000,- rata-rata per kepala keluarga. Ini salah satu betuk keadilan yang mereka kehendaki.

Secara ekonomi penerimaan dan pendapatan desa dari kebun kelapa sawit desa menunjukkan pola mirip dengan pola variabel produksi tandan buah segar tanaman yang meningkat cepat diawal periode diikuti dengan melambat dan menurun di akhir peiode produksi. Hal ini memang logis karena harga satuan TBS. Pendapatan desa diperoleh dengan cara mengurangi penerimaan biaya produksi, biaya -biaya lain (biaya perbaikan jalan ).

Berdasarkan hasil penelitian beberapa faktor yang berpengaruh positif terhadap efektifitas keberlanjutan kelembagaan kemitraan kebun kas masyarakat desa. Prinsip Ostrom (1990) tidak sepenuhnya terpenuhi yang merupakan kelemalah. Kelembagaan kemitraan yang lebih cocok dengan kareteritik pengelolaan CPR yang membutuhkan pengelolaan bersama perlu penyempurnaan prinsip-prinsip desain. Prinsip kesesuai distribusi manfaat dan biaya proporsional, aturan yang membatasi waktu dan aspek fisik yang terkait kondisi lingkungan local, sosbud, monitoring meliputi: pengawasan aktif, kompetensi pengawas, tidak ada tekanan eksternal, penerapan prinsip sanksi bertingkat dan dipatuhi, mekanisme penyelesaian konflik antara lain pengadilan, perundingan, dan cabang-cabang usaha.

Pada dasarnya Penerapan prinsip desain Ostrom (1990) dapat dilakukan dalam kelembagaan kemitraan usaha kebun kas desa, pengelolaan sumberdaya bersama termasuk lahan pertanian. Secara umum dapat disimpulkan bahwa kelembagaan kemitraan yang efektif dan berkelanjutan pada model kelembagaan kemitraan usaha kebun kelapa sawit belum terwujud dengan baik, Hasil penelitian menemukan ada beberapa prinsip desain berjalan dengan baik yakni : Batas-batas 
yang jelas (clearly defined boundaries), memberikan pengakuan atas hak pengelolaan sumberdaya bersama (lahan desa) dengan batas fisik, administratif, dan pemanfaatan hasil usaha. Perbandingan yang proporsional antara biaya dan manfaat (Proportional Equevalence between benefit and cost), adanya aturan main pengelolaan berlandaskan norma masyarakat setempat dan mengutamakan fungsi fisik sosial dan ekonomi setempat. Hasil Kesepakatan bersama ( Colective choice arrangement ), dimana para pelaku secara kolektif memberlakukan aturan dengan pola saling percaya. Prinsip desain lainnya belum dijalankan secara optimal antara lain adalah Pemantauan (Monitoring), Sanksi Berkala (graduated sanctions), Mekanisme penyelesaian perselisihan (conflict reolution mechanism), Pengakuan minimum atas hak pengelolaan (Minimal recognition of rights to organize), Pengelolaan berjenjang (nested enterprice). Untuk memperoleh model kelembagaan kemitraan usaha kebun kelapa sawit desa yang efektif dan berkelanjutan perlu melakukan penyesuaian prinsip desain ostrom dengan keadaan common pool resources yang dikelola sebagai usaha bersama. 


\section{MODEL KELEMBAGAAN KEMITRAAN USAHA KEBUN KELAPA SAWIT DESA}

(Studi Kasus Kebun Kas Masyarakat Desa Di Kabupaten Mukomuko)

Izharudin .

(Di bawah bimbingan Elfindri, Mahdi dan Melinda Noer)

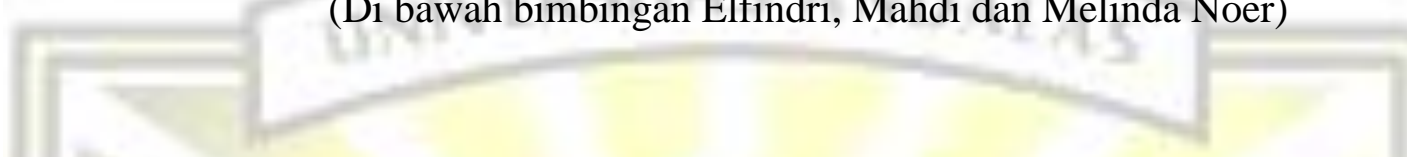

Abstrak

Kajian ini bertujuan menganalisis penerapan prinsip desain Ostrom (1990) pada kelembagaan kemitraan perkebunan kelapa sawit desa yang efektif dan berkelanjutan di kabupaten Mukomuko. Data yang digunakan merupakan data primer yang diperoleh dari hasil wawancara sebanyak 18 key informan yang terdiri dari pengelola, tokoh masyarakat, perangkat desa dan didukung kuesioner masyarakat sebanyak 180 responden. Hasil penelitian menunjukkan bahwa kelembagaan kemitraan yang ada belum berfungsi secara efektif dan belum menunjukkan keberlanjutan. Hal ini ditunjukkan oleh belum sepenuhnya prinsip-prinsip Ostrom diterapkan secara baik. Kelembagaan Kemitraan mengandalkan kepercayaan (trust) dan nilai-nilai kebersamaan. diantaranya: monitoring, sanksi berkala, dan mekanisme penyelesaian konflik. Prinsip desain yang telah menjadi kekuatan adanya batasan yang jelas atas pengakuan hak pengeloaan fisik, administratif, dan sosial. Adanya kejelasan hukum, mengatur jaminan hak dan kewajiban para aktor- aktor kelembagaan kemitraan terhadap aksi arena yang dilakukan. Dapat disimpulkan bahwa prinsip desain Ostrom dapat digunakan pada kelembagaan kemitraan usaha kebun kelapa sawit desa sebagai salah satu bentuk common, namun perlu perhatian khusus terhadap prinsip yang kurang mendapat perhatian yang layak. Disarankan hubungan kelembagaan kemitraan diformulasikan dalam suatu kontrak yang mengatur keseimbangan hak dan kewajiban dan dapat ditegakkan (enforcable contract) serta dipakai secara suka rela oleh para aktornya. Kelembagaan kemitraan pengelolaan kebun kelapa sawit dalam bentuk co-management dapat dijadikan sebagai model pengelolaan usaha yang efektif dan berkesinambungan.

Kata kunci : Kelembagaan, kemitraan, kebun kas masyarakat desa 


\section{MODEL KELEMBAGAAN KEMITRAAN USAHA KEBUN KELAPA SAWIT DESA}

(Studi Kasus Kebun Kas Masyarakat Desa Di Kabupaten Mukomuko)

Izharudin .

(Di bawah bimbingan Elfindri, Mahdi dan Melinda Noer)

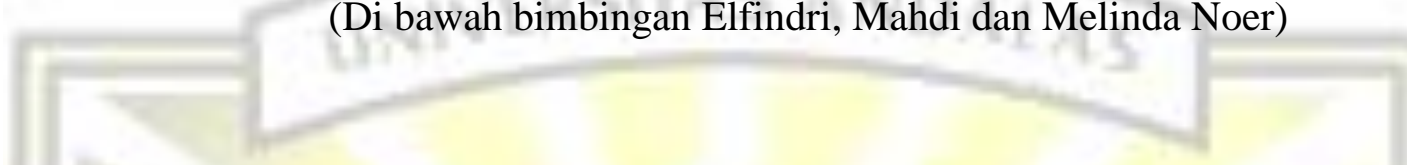

\section{ABSTRACT}

This study aims to analyze the application of the Ostrom (1990) design for institutional partnership in the oil palm plantations, and to investigate the effectiveness of village sustainably, Mukomuko district. The primary data are obtained through the interviews method of 18 key informants, community leader , village community leaders, and supported by 180 respondents. The results of the study showed that the existing institutional partnerships are not effective and not been demonstrated sustainability, It is seen that less attention or proper handling of such principles : Monitoring, periodic sanctions, conflict resolution mechanisms. The fulfilment of design principles are those clear boundaries on the recognition of rights management of physical, administrative, and social. It can be concluded that Ostrom design principles can be used in institutional partnership of village oil palm plantations as one of the common forms, but need special attention to the principle that less attention it deserves. The results showed that the existing institutional partnerships not yet effective and have not shown sustainability. This is apparent lack of legal clarity, set guarantees the rights and obligations of the partnership of institutional actors to the actions undertaken arena. Institutional Partnerships rely on trust (trust) and shared values. Suggested institutional partnership relations are formulated in a contract that regulates the balance of rights and obligations and enforceable (enforcable contract) and used voluntarily by the actors. Institutional partnership management of oil palm plantations in the form of co- management.

Keywords : institutional, partnership, Cash Village Community Plantation . 